\title{
Conversion artisanale et volonté identitaire. L'exemple des charbonniers de Moyenne Provence
}

Ada Acovitsioti-Hameau et Philippe Hameau

\section{(2) OpenEdition}

\section{Journals}

Édition électronique

URL : https://journals.openedition.org/tc/465

DOI : $10.4000 /$ tc. 465

ISSN : 1952-420X

Éditeur

Éditions de l'EHESS

\section{Édition imprimée}

Date de publication : 1 novembre 1997

ISSN : 0248-6016

\section{Référence électronique}

Ada Acovitsioti-Hameau et Philippe Hameau, «Conversion artisanale et volonté identitaire. L'exemple des charbonniers de Moyenne Provence », Techniques \& Culture [En ligne], 28 | 1997, mis en ligne le 28 octobre 2005, consulté le 29 septembre 2022. URL : http://journals.openedition.org/tc/465; DOI : https://doi.org/10.4000/tc.465

Ce document a été généré automatiquement le 29 septembre 2022.

Tous droits réservés 
Conversion artisanale et volonté identitaire. L'exemple des charbonniers de Moyenne Provence

Ada Acovitsioti-Hameau et Philippe Hameau 